\title{
講座
}

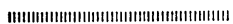

\section{応用放射線エネルギー分析法 (13)}

\section{V. ガンマ線のエネルギー分析法とその応用}

（2）ガンマ線スペクトルデータの解析法†

\section{鈴木隆司}

東京都立アイソトープ総合研究所

158 東京都世田谷区深沢 2-11-1

Key Words : gamma-ray spectrum energy calibration, peak area determination, full width half maximum, peak fitting, efficiency, self-absorption correction, coincidence summing correction, activity, detection limit

\section{はじめに}

ここでは, ゲルマニウム半導体検出器を用いた場合 のエネルギー分析に主眼を置くが，後述の応用例を念 頭に, $\gamma$ 線スペクトルのデータ解析全般について述べ る。 $\gamma$ 線スペクトル解析の手順は, ピーク探索から放 射能計算まで, 概略, 図1のと拈りである。この順番 に従って説明する。

\section{1. エネルギー校正}

$1 \cdot 1$ ピーク探索

ゲルマニウム半導体検出器で $\gamma$ 線で測定すると, コ ンプトン散乱による平担な連続部の上に光電効果によ るピークが現れる。ピークがあるかないかの判断は, コンピュータが普及していないときには，目視により いわゆるピークの形をなしているか否かをほとんど直 感により行われていた。

コンピュータによるピーク探索では，ある基準を決 めてそれにのっとって行われる。その一つとして，低 エネルギー側での立ち上がりと高エネルギー側でのた ち下がりが 3-5チャンネルあるか否かを判断させる 方法がある。より高度な方法として，平滑化二次微分 を用いる方法がある。ここでは，平滑化二次微分法に ついて述べる。

t Measurement of Radiation Energy and Its Application(13). V.Measurement of gamma-ray energy and its application. (2) Analyses of gamma-ray spectrum data. Takashi SUZUKI: Tokyo Metropolitan Isotope Research Center, Fukasawa 2-chome, Setagaya-ku, Tokyo 158.

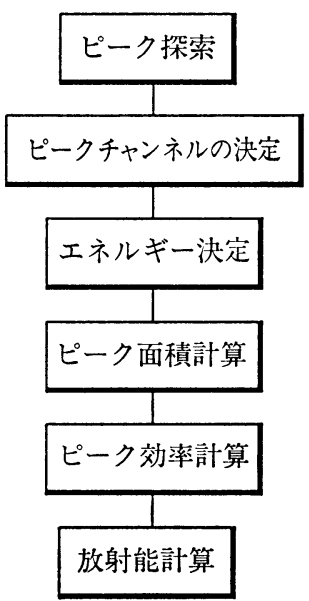

図 $1 \gamma$ 線スペクトルの解析手順

$i$ チャンネルの計数值を $n(i)$ とすると, $(2 k+1)$ チ +ンネルの値を用いて平滑化二次微分を施した数值 $n^{\prime \prime}(i)$ はづのように表される。

$$
n^{\prime \prime}(i)=\sum_{j=-k}^{k} a_{j} \cdot n(i+j)
$$

ただし， $\sum_{j=-k}^{k} a_{j}=0$ である。

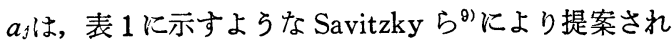
た定数を用いる。 $n^{\prime \prime}(i)$ に対する統計変動は次式で与 えられる。

$$
\sigma^{\prime \prime}(i)=\left\{\sum_{j=-k}^{k} a_{j}{ }^{2} \cdot n(i+j)\right\}^{1 / 2}
$$

実際のスペクトルに対して平滑化二次微分を計算した 例を図 2 に示す。 
表 1 ピーク探查に用いられるフィルタ関数の定数 ${ }^{11}$

\begin{tabular}{l|r|r|r|r|r|r|c|c}
\hline 名 & $2 k+1$ & \multicolumn{1}{c|}{$a_{0}$} & $a_{1}, a_{-1}$ & $a_{2}, a_{-2}$ & $a_{3}, a_{-3}$ & $a_{4}, a_{-4}$ & $a_{5}, a_{-5}$ & $a_{6}, a_{-6}$ \\
\hline ガウス関数二次 & 7 & -10 & -1 & 5 & 1 & & & \\
微分 & 9 & -10 & -3 & 4 & 3 & 1 & & \\
& 13 & -8 & -5 & -1 & 4 & 3 & 2 & 1 \\
\hline 多項式最小自乗 & 7 & -4 & -3 & 0 & 5 & & & \\
(Savitzky $^{9}$ ) & 9 & -20 & -17 & -8 & 7 & 28 & & \\
& 13 & -14 & -13 & -10 & -5 & 2 & 11 & 22 \\
\hline
\end{tabular}
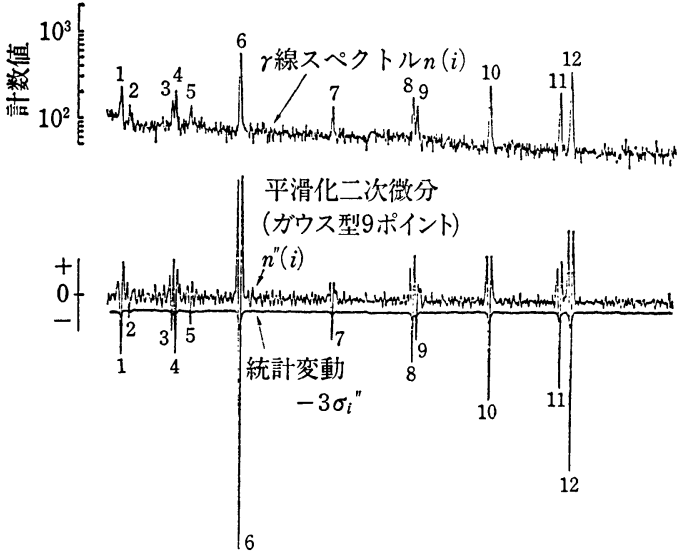

図 2 平滑化二次微分によるピーク探査 ${ }^{11}$

$\left|n^{\prime \prime}(i)\right|>b \sigma^{\prime \prime}$ の条件を満足する場合にピークと判定 される。 $b$ は感度を与える定数であるが, $2-3$ の值 を用いる。この值が小さいほど微少なピークも判定し 得ることになるが，変動分をピークと見違えるおそれ がある。

\section{$1 \cdot 2$ ピーク中心チャンネルの決定}

ピークの中心チャンネルを求めることは， $\gamma$ 線のエ ネルギーそのものを求めることであり, エネルギー分 析における最も大切な項目である。これが充分な精度 で得られない場合には，核データとしての $\gamma$ 線エネル ギー測定あるいは, 放射化分析, 環境放射能分析等の応 用分析のさいに，誤った結果をもたらすことになる。

この方法は, 種々提案されているので, ここではい くつかの方法について述べる。

\section{$1 \cdot 2 \cdot 1$ 一次微係数ゼロクロス法}

この方法は, ピークの中心を含む $5-7$ チャンネルの 間で, 一次微係数がゼロを横切る点を求めるものであ る。図 3 に示すように，ピーク中心の前後で一次微係 数は直線で近似される。真のピークチャンネルを含む 2 チャンネルの計数值を $m, m+1$, 一次微係数を $\Delta n_{m}$, $\Delta n_{m+1}$ とすると, 真のピーク中心チャンネル $p$ は次式

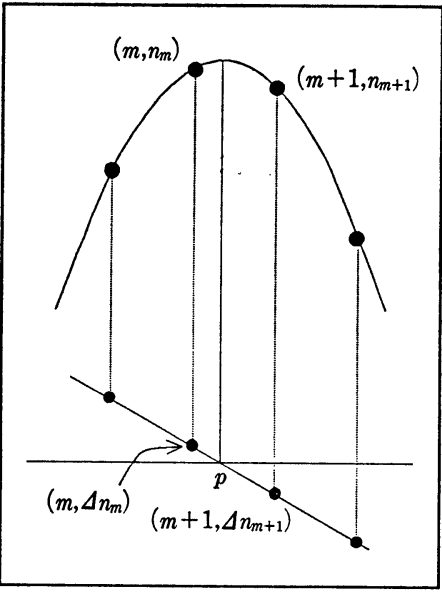

図 3 一次微係数ゼロクロス法 ${ }^{11}$

表 2 一次微係数を求めるさいに用いる フィルタ関数の定数 ${ }^{91}$

\begin{tabular}{c|c|c|c|c|c|c}
\hline $2 k+1$ & $c_{0}$ & $c_{1}, c-1$ & $c_{2}, c-2$ & $c_{3}, c_{-3}$ & $c_{4}, c-4$ & $N_{m}$ \\
\hline 5 & 0 & $1,-1$ & $2,-2$ & & & 10 \\
7 & 0 & $1,-1$ & $2,-2$ & $3,-3$ & & 28 \\
9 & 0 & $1,-1$ & $2,-2$ & $3,-3$ & $4,-4$ & 60 \\
\hline
\end{tabular}

により求められる。

$$
p=m+\frac{\Delta n_{m}}{\Delta n_{m}-\Delta n_{m+1}}
$$

ただし， $\Delta n_{m}>0$, かつ $\Delta n_{m+1} \leqq 0$ を満足しなければな らない。なお, 一次微係数 $\Delta n_{i}$ は, 次式で計算される。

$$
\Delta n_{i}=\frac{1}{N_{m}} \sum_{j=-k}^{k} c_{j} \cdot n_{i+j}
$$

ただし， $N_{m}$ は規格化定数であり， $c_{j}$ は表 2 で与えら れる。

\section{$1 \cdot 2 \cdot 2$ 指数関数に変換する方法}

ピークの形がガウス分布であると仮定し，ピーク全 体に対して次式を計算する。

$$
Z(i)=n(i-1) / n(i+1)
$$

$Z(i)$ は, 単純な指数関数で表されるので, 片対数用紙 


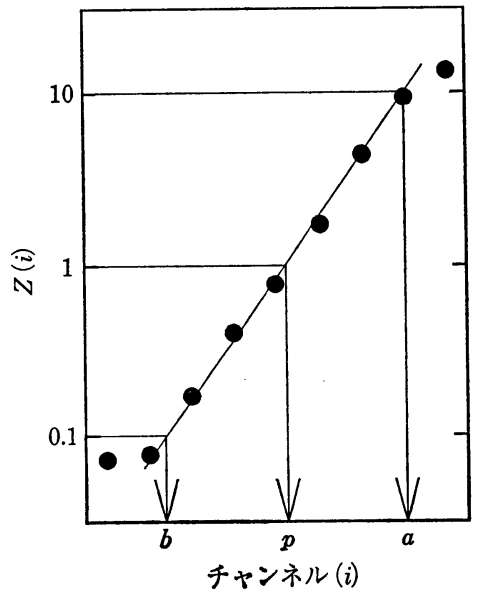

図 4 指数関数変換の方法 ${ }^{2}$

の横軸にチャンネル，糈軸に $Z(i)$ をとってプロットす ると図 4 のように $Z(i)$ が0.1から10の範囲で直線に近 似される。この図より, $Z(i)=1$ なるャンネル $p$ がピ 一ク中心チャンネルである。

$1 \cdot 2 \cdot 3$ ピークの重心を用いる方法

重心の概念を用い, 半值幅 (1・3で説明) の 3 倍程度 の領域 (ピーク計数值が最大であるチャンネルをほぼ 中心にしてチャンネル $l-r)$ でつぎのような計算をす ることによりピーク中心チャンネルを求めることがで きる。

$$
p=\sum_{i=l}^{r}[i \cdot n(i)] / \sum_{i=l}^{r} n(i)
$$

しかし,この方法はピークの対称性が悪いとピーク位 置がずれてしまう。

\section{$1 \cdot 2 \cdot 4$ ピーク近傍の 3 点計数值による方法}

ピークの計数值が比較的高く, 統計変動が小さいと きは，ピーク近傍の 3 点を用いて求めることができ る。図 5 に示すように, 最も計数值の高いチャンネル を $m$, その計数値を $n_{m}$, その前後のチャンネル $m+1$ と $m-1$ の計数值を $n_{m+1}, n_{m-1}$ とする。この 3 点を二

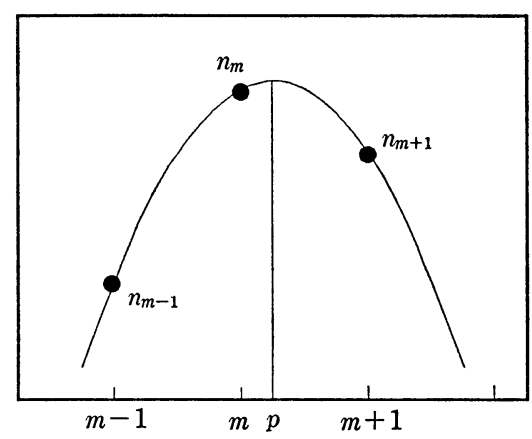

困 53 点計数值によるピーク中心 ${ }^{11,2)}$
次式で近似すると，ピーク中心チャンネルは次式で表 される。

$$
p=m+\frac{1}{2}\left[\frac{n_{m+1}-n_{m-1}}{2 n_{m}-n_{m-1}-n_{m+1}}\right]
$$

ガウス関数で近似すると, 次式より求められる。

$$
p=m+\frac{1}{2} \cdot \frac{\ln \left(n_{m+1} / n_{m-1}\right)}{\ln \left(n_{m}{ }^{2} / n_{m+1} \cdot n_{m-1}\right)}
$$

$1 \cdot 2 \cdot 5$ 関数フィッティング法

より高度で複雑な方法に，ピーク全体を関数に当て はめる関数フィッティング法がある。適合する関数が つぎのようなガウス関数と直線で表される場合を考え る。

$$
F=d_{1}+d_{2}(i-p)+d_{3} f(i)
$$

ただし，

$$
f(i)=\exp \left[-2.773\left(\frac{i-p}{w}\right)^{2}\right]
$$

ここで, $d_{1}, d_{2}, d_{3}$ は定数, $p$ はピーク中心チャンネ ル，wは半值幅である。これらの未知パラメータに対 して初期值を設定し, 非線形最小自乗法を適用して未 知パラメータがある值に収束するまで計算を繰り返 す。このようにしてピーク中心チャンネルрが求めら れる。式( 9 )のような単純な例はまれで，より実測値 に合うように種々の関数が付加される。一例を図 6 に 示す。しかし，パラメータの数が増えればそれだけ計 算時間が長くかかり，収束の度合いも悪くなることを 考慮しなくてはならない。

以上ピーク中心チャンネルの求め方の例を述べてき たが，最も精度良くピーク中心チャンネルを求める方 法は，関数フィッテング法である。このような複雑な 方法は, 以前は汎用の大型コンピュータあるいはミニ コンでしか計算できなかったが，パーソナルコンピュ 一タの出現，そして，急速な発展と普及により，だれ もが手軽に計算可能となってきた。

\section{$1 \cdot 3$ 半値幅 (FWHM)}

光電ピークは生成電荷のゆらぎのみならず, 測定系 に起因する雑音等により広がりを持つ。そのため, 測 定系の性能評価のため半值幅の值を定期的に測定する 必要がある。さらに, ピーク解析を行らさいにもこの 半值幅の值が用いられるので，ここで半值幅について 説明を加えておく。

半値幅の定義は, 図 7 に示すように, ピークの高さ の 2 分の 1 の高さでのピークの広がりをいい, チャン ネルあるいはエネルギーの単位で表される。半值幅の 值は, $1 \cdot 2 \cdot 2$ から次式により求められる。 


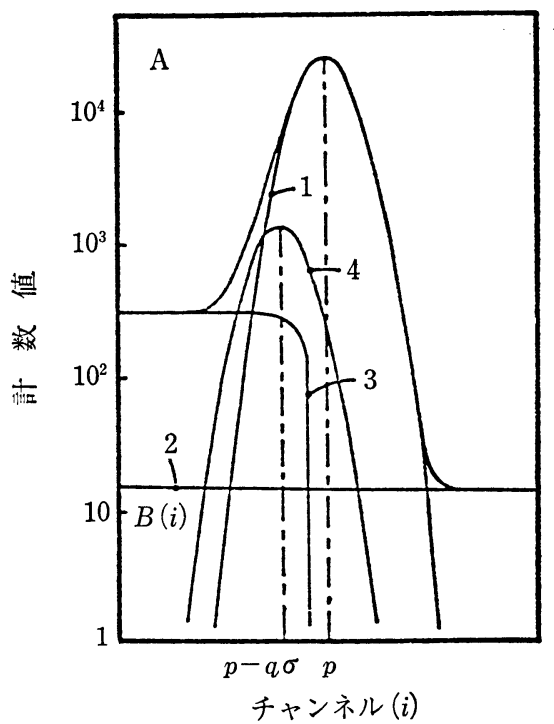

図 6 関数適合の例 ${ }^{1), 13), 14}$

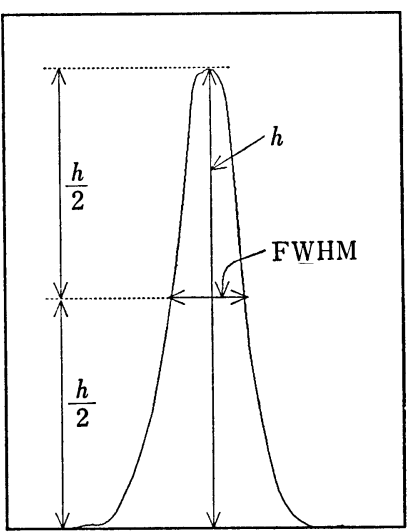

図 7 半值幅 (FWHM)

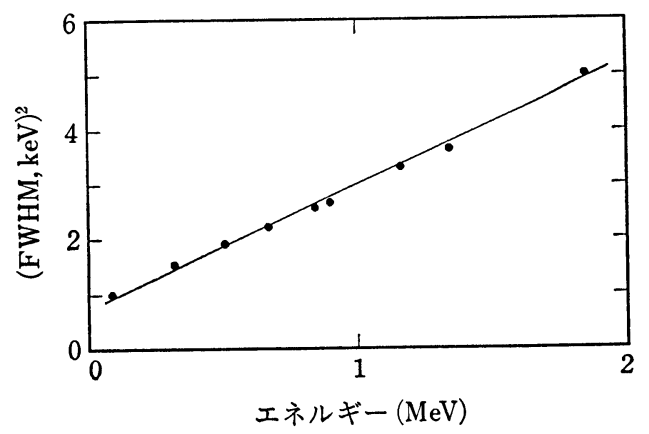

図 8 エネルギー対 $(\mathrm{FWHM})^{2}$

$$
\mathrm{FWHM}=1.552 \sqrt{a-b}
$$

ただし， $a$ とbは $Z(i)$ がそれぞれ10，0.1となるチャ ンネルである。また, 半值幅の值は $1 \cdot 2 \cdot 5$ からwの值

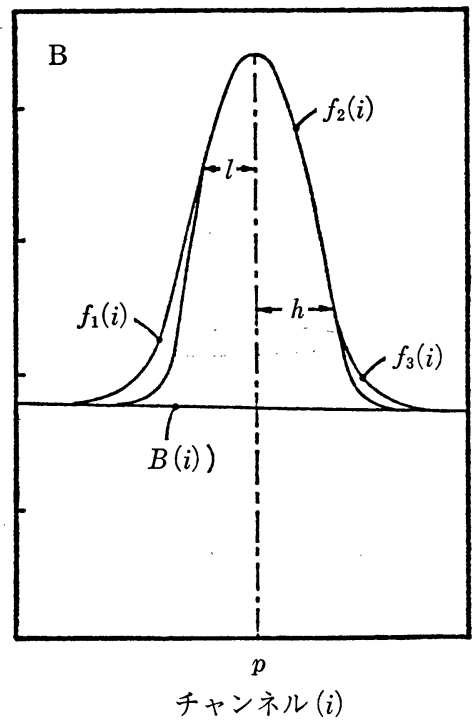

(図中の各関数は文献参照)

としても求められる。

半值幅は, エネルギー依存性がある。図 8 に相対効 率 $28 \%$ の $\mathrm{Ge}$ 半導体検出器の場合についてェネルギー 対(FWHM) $)^{2}$ の関係を示した。

\section{$1 \cdot 4$ エネルギー校正曲線の作成}

ゲルマニウム半導体検出器を用いたエネルギー分析 では，エネルギーの絶対測定はできず，エネルギー既 知のピークとの相対測定から求められる。

核データ表(10),11)を参考にすると，核種ごとに放出 される $\gamma$ 線のエネルギーを調べることができる。この なかから, 求めたいェネルギー範囲について, エネル ギー既知の核種 $(80 \mathrm{keV}-2 \mathrm{MeV}$ をガーしている単 一あるいは複数の核種) を選ぶ。標準となる核種は， 本講座(12)の表 2 を参考にするとよい。これらを用い

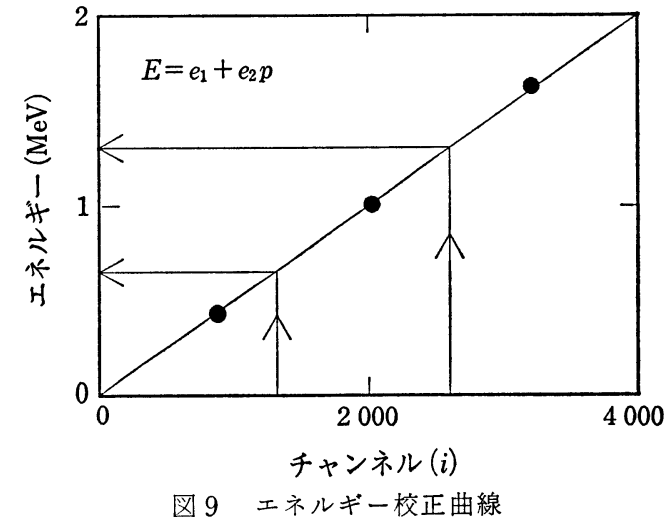




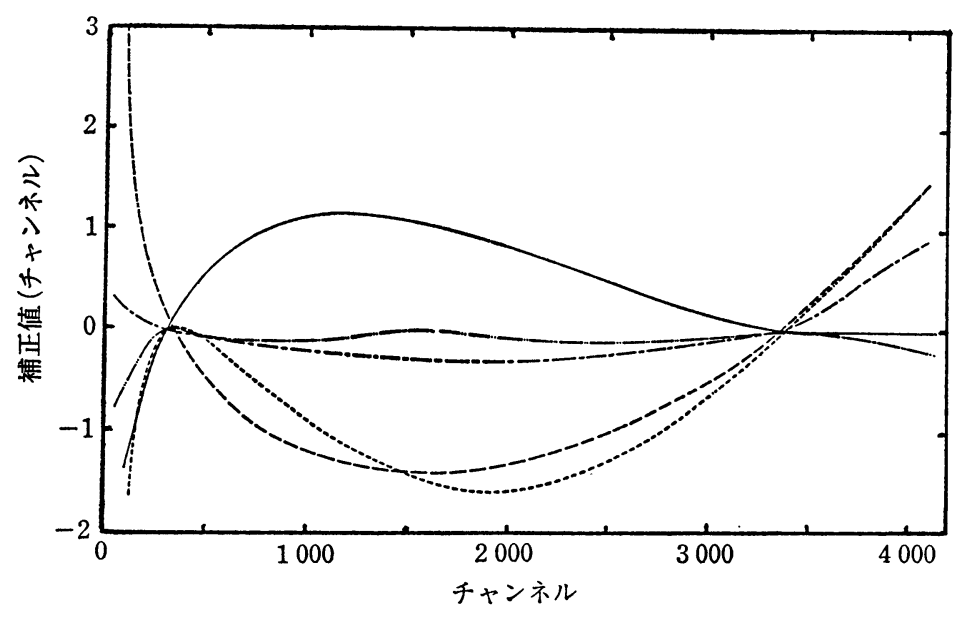

四105台の $\mathrm{Ge}(\mathrm{Li})$ 検出器システムの非直線性 ${ }^{12}$ )
をチャンネルの関数で求めておき, その值をEに加算することによりよ り正確なエネルギーが求められる。 あるシステムの $\Delta E$ とチャンネルの 関係を図11に示す2)。

\section{2. ピーク面積}

核種から放出される ぞれ核種により特有のエネルギーを 持っており,また, 光電ピークは放 射能の強さに比例して増大する。そ のため，後述する $\gamma$ 線応用分析を行 らさいには, 光電ピークの面積を放 射能既知の標準線源との比較により 定量分析が行われる。

$\tau \gamma$ 線を測定し, 得られたピークの中心チャンネルを 上記の方法で求めるとエネルギーとチャンネルの関係 であるェネルギー校正曲線が得られる。困 9 がェネル ギー校正曲線の模式図である。

実験より得られた結果をつぎのような一次式に関数 フィッテングする。

$$
E=e_{1}+e_{2} p
$$

ここで, $e_{1}, e_{2}$ は定数, $E$ はエネルギー, $p$ はピーク中 心チャンネルである。この校正曲線を使用することに より, 未知ピークのエネルギーを求めることが可能と なる。しかし, 測定システムは, おむに増幅器や ADC の性能により積分直線性に歪が生じ，ピーク中心チャ ンネルが変化する。一例として, 図10に Helmer らが

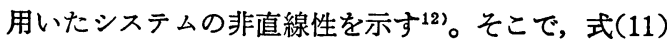
で計算されたェネルギーと真のエネルギーとの差 $\Delta E$

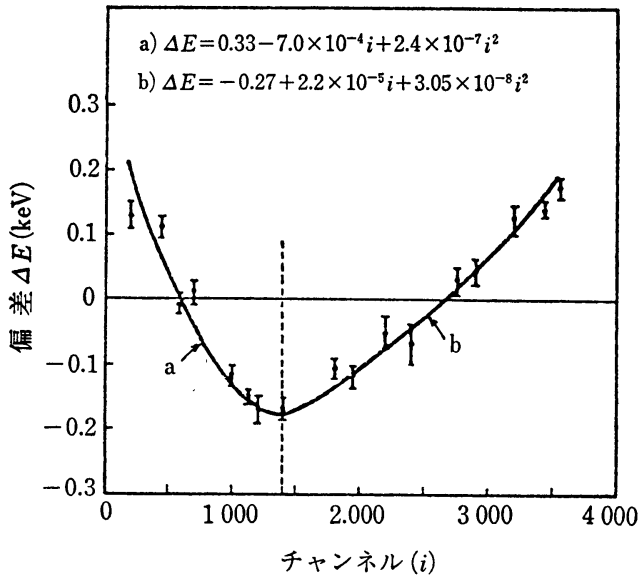

図11 エネルギー校正における直線関係 からの偏差 $\Delta E$ の例 ${ }^{2}$

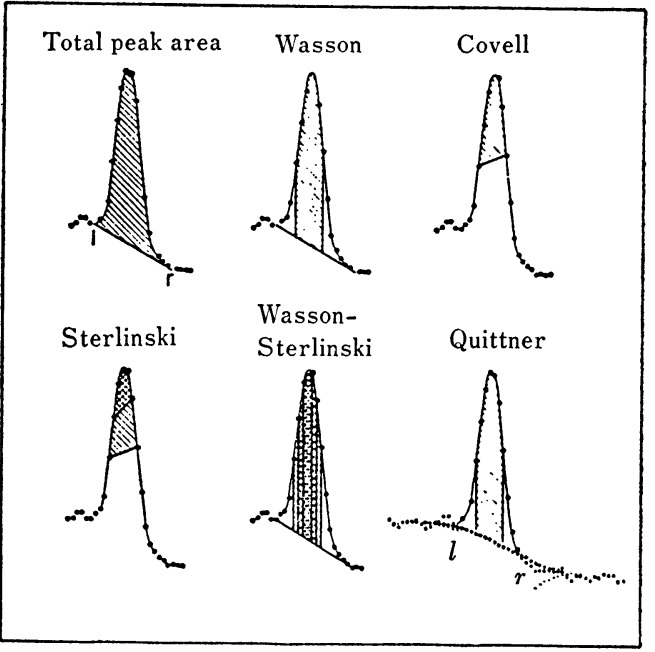

図12 ピーク面積の計算方法 ${ }^{3), 4)}$

光電ピーク面積の求め方に, 生データを直接扱ら方 法と，ある関数に適合して積分する方法の二つに大別 される。

\section{$2 \cdot 1$ 単一ピークの場合}

前者の方法を用いた最も単純な単一ピークの場合に ついては，図12に示すよらに種々の方法が提案され

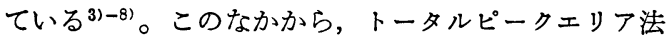
（TPA法）の計算方法を図13で説明する。

ピーク領域はピークの左右のすそ野まで（チャンネ ル $l-r)$ とし, 必ずしも最大ピークチャンネルから左 右同じチャンネル数とは限らない。そこからさらにm チャンネルをベースラインを考慮する領域とし, それ 


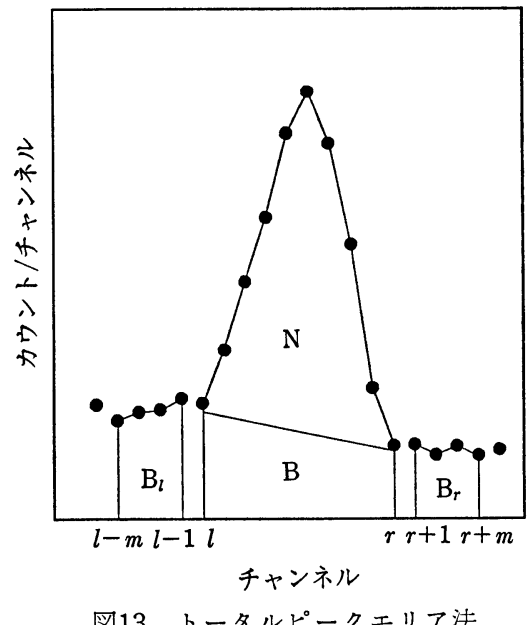

ぞれの領域の加算したカウント数を $B_{l}, B_{r}$ とすると， 正味のピーク面積は次式で与えられる。

$$
N=\sum_{i=l}^{r} n(i)-\left(B_{l}+B_{r}\right)(r-l+1) / 2 m
$$

この場合のピーク面積に対する計数誤差は, 誤差論よ り次式で与えられる。

$$
\sigma_{N}=\sqrt{\sum_{i=l}^{r} n(i)+\left(B_{l}+B_{r}\right)(r-l+1) /{ }^{2} 4 m^{2}}
$$

単一の独立したピークであるが，近傍のベースライ ンに妨害ピークが存在する場合の処理方法は, 科学技 術庁のマニュアル2)に詳しく記述されている。

\section{$2 \cdot 2$ 複合ピークの場合}

解析領域の中に, 二つのピークが重なっている場合 がある。分析するピークは, なるべく単一のものを選 ぶべきであるが，複合ピークしかないときにはつぎの ようにする。

2 本のピークが同一核種の場合には, 両ピークを含 めたピーク面積を計算し, それぞれの $\gamma$ 線放出比の割 合で振り分ける。異なった核種が重なっていて，かつ 妨害している核種に基準となるピークが他にある場合 については, 寄与係数りを用いて補正する。すなわ ち，妨害ピークおよび妨害基準ピークの $\gamma$ 線放出比を

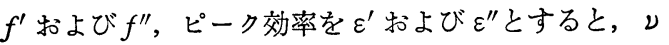
は式(14)のように表される。

$$
\nu=f^{\prime} \cdot \varepsilon^{\prime} / f^{\prime \prime} \cdot \varepsilon^{\prime \prime}
$$

このレを用いて妨害ピークのカウント数を計算し, 全 ピーク面積より差し引くことにより対象とするピーク の面積が計算される。

ピークの形がガウス関数で, 両ピークの中心チャン
ネルおよび半值幅が分かっている場合には, 連立方程 式を用いて計算される2)。

$2 \cdot 3$ 関数フィッティング法

ピークが接近しているとき，あるいは複合している ときには, 上記の方法ではバックグラウンドの差引に 問題が生じてくる。このようなときには, 関数フィッ ティング法が有効である。

あらかじめピーク中心チャンネル(p)とそのピーク の半值幅 (w)が分かっている場合には線形最小自乗法 が適用できる。適合する関数として式 (9)にさらにガ ウス関数を一つ付加したつぎのような場合を考える。

$$
F(i)=d_{1}+d_{2}\left(i-p_{1}\right)+d_{3} f_{1 i}+d_{4} f_{2 i}
$$
ただし，

$$
\begin{aligned}
& f_{1 i}=\exp \left[-2.773\left(\frac{i-p_{1}}{w_{1}}\right)^{2}\right] \\
& f_{2 i}=\exp \left[-2.773\left(\frac{i-p_{2}}{w_{2}}\right)^{2}\right]
\end{aligned}
$$

解析領域で, 計数值と適合関数の值との差の自乗和を 最小にするように $d_{j}(j=1-4)$ を求めると, 二つのピ 一ク面積は次式により簡単に求められる。

$$
\begin{aligned}
& N_{1}=1.064 d_{3} w_{1} \\
& N_{2}=1.064 d_{4} w_{2}
\end{aligned}
$$

ピーク中心チャンネルや半值幅も未知数である式 (17)のような関数の時には, 非線形最小自乗法を適用 する。

$$
\begin{aligned}
f_{1}= & d_{1}+d_{2}\left(i-d_{5}\right) \\
& +d_{3} \exp \left[-d_{4}\left(i-d_{5}\right)\right]
\end{aligned}
$$

ただし， $d_{4}=2.773 / \omega^{2}$ である。

未知パラメータに対して, 初期值を設定し, パラメ 一タがある值以下に収束するまで計算を繰り返す。ピ 一ク面積は, 次式で与えられる。

$$
\begin{aligned}
N & =1.064 d_{3} w \\
& =1.172 d_{3} / d_{4}{ }^{1 / 2}
\end{aligned}
$$

\section{3. ピーク効率}

\section{$3 \cdot 1$ ピーク効率曲線の作成}

ピーク効率は, 線源や検出器の大きさ, 形状あるい は線源との幾何学的条件, エネルギーにより異なる。 ある試料中の放射能を計算するためには, 同一検出器 を使用し，目的とする試料と同じ母材の試料で放射能

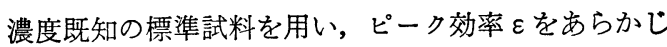
め求めて拉く必要がある。ピーク効率はすでに本講座 (12)で述べたように, 次式で表される。 


$$
\varepsilon=\frac{N}{A \cdot f \cdot t}
$$

ここで, $N$ は光電ピークのカウント数， $A$ は放射能強 度” $(\mathrm{Bq}), f$ は $\gamma$ 線放出比, $t$ は測定時間 $(\mathrm{s})$ である。 対象とする試料の中に, 複数の未知核種が含まれてい る場合には，それぞれについてピーク効率を求めるこ とになるが，すべての核種について標準線源が用意さ れているわけではないので，その場合には複数の標準 線源によりェネルギー対ピーク効率曲線を求めておか なくてはならない。

ピーク効率の関数としては, 式(20)や式(21)が用い られ ${ }^{15), 16)}$, 最小自乗法により係数 $g_{i}(i=1-6)$ を求め る。

$$
\begin{aligned}
& \ln \varepsilon(E)=g_{1}+g_{2} \ln E+g_{3}(\ln E)^{2} \\
& \varepsilon(E)=g_{1} E^{-g_{2}}+g_{3} \mathrm{e}^{-g_{4} E}+g_{5} \mathrm{e}^{-g_{6} E}
\end{aligned}
$$

ただし，Eはエネルギーを表す。

この関数を用いても，全エネルギー範囲を 5-10\% 以内の誤差で表すことはできない。エネルギー範团を 2-3に分割してそれぞれに対して係数を求めて打く のが良い。

測定試料は点とは限らず,面状に広がったもの, ある いは大量の試料をそのまま測定する場合には容積を持 つことになる。このような試料の測定のさいには，標 準となる線源として，適当な核種を含んだ面線源や容 積線源も供給されているので場合により使い分ける。

容積線源を用いる場合, 常に同一の容積の試料が得 られるとは限らない。このような場合には, 試料の高 さが異なる種々の容積線源（母材としてパーライト， 寒天，アルミナ，二酸化マンガン等がアイソトープ協 会から入手可能）でェネルギー効率曲線を求め, 高さ の補正を内挿法で求めれば種々の高さの試料でのピー

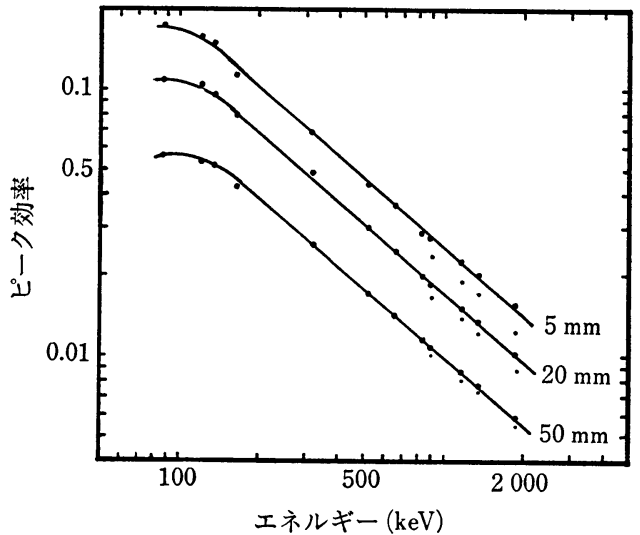

図14ピーク効率曲線（高エネルギー領域に おける各曲線から下にはずれた 4 点 は, サム効果の補正をしない場合)
ク効率が求められる。

ポリスチレン製容器 $(48 \mathrm{~mm} \phi)$ に母材としてアルミ ナ $5 \mathrm{~mm}, 20 \mathrm{~mm}, 50 \mathrm{~mm}$ 高さを使用した容積線源を， 相対効率 $28 \%$ の $\mathrm{Ge}$ 半導体検出器を用いて湘定した場 合の効率曲線を図14亿示す。

\section{$3 \cdot 2$ 自己吸収の補正}

$\gamma$ 線は $\alpha$ 線， $\beta$ 線に比べて透過力が大きく，点線源 と見なせるものであれば自己吸収は問題にならない。 しかしながら, 湘定試料の量が増加し, 円筒形容器あ るいはマリネリ形容器を用いる場合, 試料それ自体に よる吸収が顕著になってくる。モンテカル口計算によ ると, U-8 容器 (ポリスチレン製 : $48 \mathrm{~mm} \phi$ ) に密度 1 の寒天を $5 \mathrm{~cm}$ 入れた場合, $122 \mathrm{keV}$ の 線の自己吸収 割合は 0.76 となり, 密度 2.46 の二酸化マンガンの場 合は 0.50 である ${ }^{22}$ (図15)。

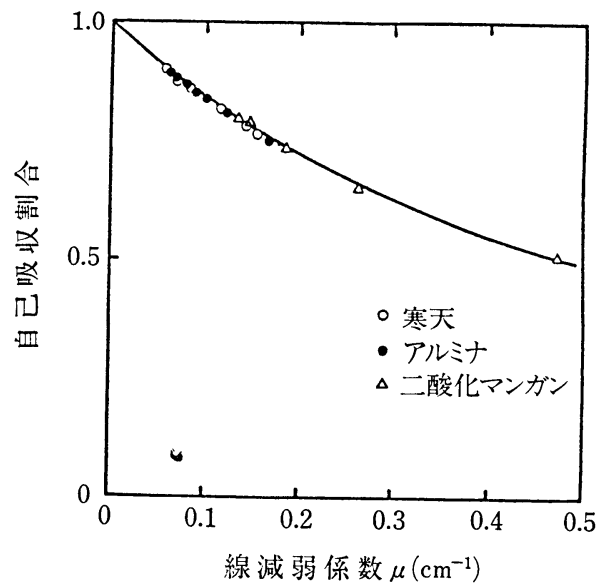

図15 ポリスチレン製容器 $(48 \mathrm{~mm} \phi \times 50 \mathrm{~mm})$ に母材として寒天, アルミナ，二酸化マ ソガンを用いた場合の自己吸収割合 ${ }^{22}$

標準の容積線源と同じ母材(マトリクス)の試料を測 定する場合には，自己吸収の補正は必要としないが, 母材が異なったときには自己吸収の補正をしなくては ならない。

自己吸収の補正は, 実験的方法 ${ }^{17)}$, 半実験的方法 ${ }^{18)-}$ 20)，モンテカルロ法21),22) で行われる。実験的方法は, 簡単な比例計算で補正されるが, 数多くの標準容積線 源が必要となる。半実験的方法には, 点線源効率積分 法がある。容積線源が必要なく, 標準点線源が一つあ ればよいが, 多数の点線源効率データが必要となる。 モンテカルロ法は, 標準線源の測定を必要としない。 しかしながら, あらかじめ検出器有感部の形状を明確 にするための測定が必要となる。 


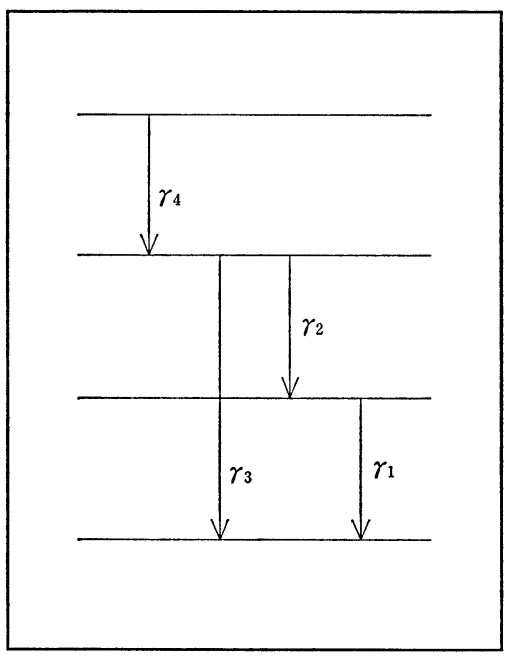

図16 サム効果を生ずる $\gamma$ 遷移

\section{$3 \cdot 3$ サム効果の補正}

図16のように 4 本の $\gamma$ 線を放出するような単純な崩 壊形式を持つ核種を仮定し，着目する $\gamma$ 線を $\gamma_{3}$ とす る。 $\gamma_{1}$ と $\gamma_{2}$ が同時に全エネルギーを吸収されると, $\gamma_{3}$ と同じェネルギーの吸収が起こったことと同じにな るので, ピーク計数率は増加する。また, $\gamma_{3}$ が全エネ ルギー吸収されると同時に, $\gamma_{4}$ が光電効果, コンプト ン効果, 電子対生成等の相互作用をすると, $\gamma_{3}$ のエネ ルギーよりも高くなってしまい $\gamma_{3}$ の計数率は減少す る。これらの現象をサム効果と呼ぶ。 ${ }^{60} \mathrm{Co}$ は本講座 (12)で述べられているように, 原子核が 1 崩壊するご とに二つの $\gamma$ 線がカスケードに放出されるので, それ ぞれのェネルギーのピーク計数值は減少し, 見かけ上 検出効率が低下する。サム効果は, 検出器の大きさが 大きい場合, 線源の強さが強い場合あるいは検出器と 線源間距離が近い場合に顕著になる。

サム効果の補正方法には，計算による方法と基準ピ ーク効率をゼロに補外する方法がある1”。

たとえば，計算による方法で補正を行うと， ${ }^{60} \mathrm{Co} の$ 場合は次式により求められる。

$$
\begin{aligned}
& \varepsilon_{1.17}=\varepsilon^{\prime}{ }_{1.17} /\left(1-T_{1.33}\right) \\
& \varepsilon_{1.33}=\varepsilon^{\prime}{ }_{1.33} /\left(1-T_{1.17}\right)
\end{aligned}
$$

ここで， $\varepsilon^{\prime}$ は補正前のピーク効率を， $T$ は全効率（ス ペクトルの全カウント数/全 $\gamma$ 線放出数)を表す。

基準ピーク効率をゼロに外挿する方法は，ピーク効 率のうち幾何学的要素を基準とする $\gamma$ 線のピーク効率 と比較することにより消去しようとするものである。 自己吸収が補正されたものであれば，この方法は，容
積線源にも適用される。

\section{4. 放射能の計算}

$4 \cdot 1$ 放射能の計算

試料中の放射能 $(A: \mathrm{Bq})$ は，式 (19) を書き換え ることにより，つぎのように計算される。

$$
A \pm \sigma_{A}=\frac{N \pm \sigma_{N}}{\varepsilon \cdot f \cdot t}
$$

試料の単位重量当たりの放射能を求めたい場合，あ るいは試料を濃縮した場合にはそれぞれの值でさらに 除す必要がある。

\section{$4 \cdot 2$ 減衰補正}

放射性核種が単位時間当たりに崩壊する原子核の数 はその時点での原子核の数に比例する。すなわち，次 式の関係がある。

$$
-\frac{\mathrm{d} N}{\mathrm{~d} t}=\lambda \cdot N
$$

初期条件を $t=0$ の時 $A=A_{0}$ として, 式(24)を積分し, 放射能の関係に直すと次式が得られる。

$$
A=A_{0} \exp (-\lambda t)
$$

すなわち, $t=0$ での放射能の值は，次式により減衰補 正される。

$$
A_{0}=A \exp (+\lambda t)
$$

半減期の短い核種ほど測定中の減衰が顕著になる が，このような場合には，測定中の減衰補正も行う。 これは，式(26)の右辺につぎの項を乗ずることにより 行われる。

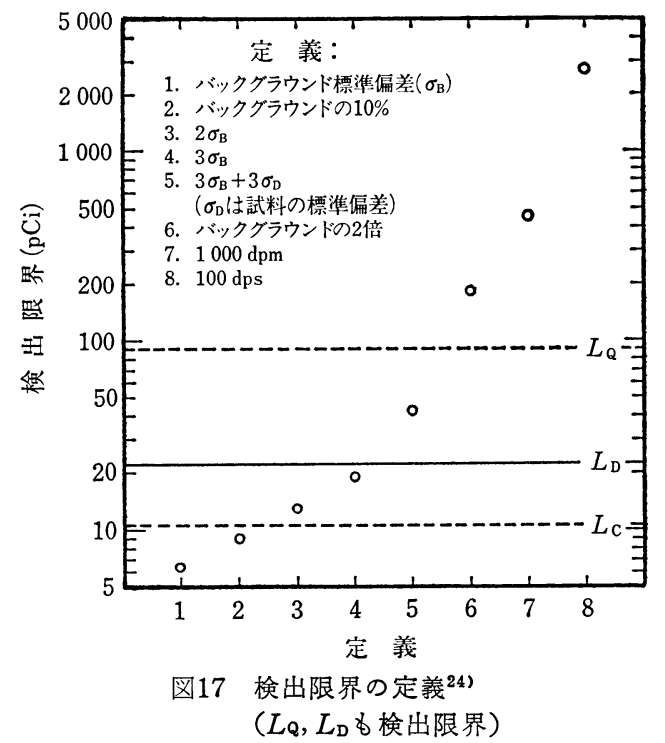




$$
\begin{gathered}
\lambda t_{\mathrm{m}} /\left\{1-\exp \left(-\lambda t_{\mathrm{m}}\right)\right\} \\
\text { ここで, } t_{\mathrm{m}} \text { は測定時間を表す。 }
\end{gathered}
$$

\section{$4 \cdot 3$ 検出限界}

検出された值が有意なものであるか否かは, 測定系 の検出限界を把握して和く必要がある。検出限界の定 義には非統計的なものから数学的に導き出されたもの まで種々のものがある23),24)。一例を図17亿示す。

四中の $L_{\mathrm{c}}$ は，ピークが存在しないのに存在すると 結論づける危険率 $\alpha$ （第一種のエラー）に関係した値 で, 臨界值と呼ばれる。 $L_{\mathrm{D}}$ は, 第一種のエラーと,ピ 一クが存在するのに存在しないと結論づける危険率 $\beta$ （第二種のエラー）から導かれる検出限界で, 次式に より計算される。

$$
L_{\mathrm{D}}=L_{\mathrm{O}}+\frac{k_{\beta}{ }^{2}}{2}\left[1+\left(1+\frac{4 L_{\mathrm{O}}}{k_{\beta}{ }^{2}}+\frac{4 L_{\mathrm{O}}{ }^{2}}{k_{\alpha}{ }^{2} k_{\beta}{ }^{2}}\right)^{1 / 2}\right]
$$

ただし， $k_{\alpha}, k_{\beta}$ は危険率 $\alpha, \beta$ により定義される定数で ある。 $5 \%$ の危険率を見込むと $k_{\alpha}, k_{\beta}$ の值は1.64 計 算される。LQは，ある一定の精度以上で検出できる最 小のカウント数として定義される検出限界 (Cooper も 引用 ${ }^{25)}$ ) で，次式により計算される。

$$
L_{Q}=\frac{k_{Q}^{2}}{2}\left[1+\left(1+\frac{4 B}{k_{Q}^{2}}\right)^{1 / 2}\right]
$$

ただし， $k_{8}$ の逆数は必要とする相対標準偏差であり， 10\%の相対標準偏差でピーク面積 (あるいは放射能) を求めたいときには $k_{Q}$ の值は10となる。

\section{5. 解析用ソフト}

一昔前までは，MCA で得られたデータはプリンタ あるいはプロッタに出力されるのが一般的であった。 それらのデータを目視によりピークを抽し出し，電卓 でピーク面積を計算していた。ところが，パーソナル コンピュータの普及により，MCA とコンピュータと が接続されるようになり，今まで電卓に頼っていた解 析がコンピュータにとって変わった。それにより, 計 算時間の飛躍的な短縮となり, 乙か子確実な結果が得 られるようになった。

コンピニータによる解析の方法は, 自作ソフトを使 用する場合と，既製のソフトを使用する場合がある。 自作の場合は，手計算により行っていた方法をとりあ えずそのまま移植することでも良い。また，ピークサ 一チやピーク面積の計算をここに述べたようなより解 析的な方法で行っても良い。自作の場合は計算の内容 に，柔軟性を持たせられる。
ルーチン的な仕事に用いる場合には，既製のソフト で充分であろう。この場合既成のソフトの適用範囲を 充分知った上で使用すべきである。たとえば，環境放 射能測定の市販ソフトは, 科学技術庁のマニュアルに 沿って作られて打り，1979年版マニュアル2)では，自 己吸収あるいはサム効果の補正は行われていない。

\section{文献}

1）野口正安: “ $\gamma$ 線スペクトロメトリー”，日刊工 業新聞社，東京 (1980)

2）科学技術庁：“放射能測定法シリーズ,ゲルマニ ウム半導体検出器を用いた機器分析” (1979)

3) Baedecker, P.A.: Anal. Chem., 43, 405-410 (1971)

4) Kokta, L.: Nucl. Instr. \& Methods, 112, 245-251 (1973)

5) Covell, D.F.: Anal. Chem., 31, 1785-1790 (1959)

6) Sterlinski, S.: ibid., 40, 1995-1998 (1968)

7) Quittner, P.: ibid., 41, 1504-1506 (1969)

8) Quittner, P.: Nucl. Instr. \& Methods, 76, 115-124 (1969)

9) Savitzky, A. and Golay, M.J.: Anal. Chem., 36, 1627-1639 (1964)

10) Lederer, C.M. and Shirley, V.S.: "Table of Isotopes", 7 th ed., John Wiley \& Sons (1978)

11) Browne, E. and Firestone, R.B.: "Table of Radioactive Isotopes", John Wiley \& Sons (1986)

12) Helmer, R.G., Greenwood, R.C. and Gehrke, R.J.: Nucl. Instr. \& Methods, 96, 173-196 (1971)

13) Robinson, D.C.: ibid., 78, 120-124 (1970)

14) Routti, J.T. and Prussin, S.G.: ibid., 72, 125142 (1969)

15) Kane, W.R. and Mariscotti, M.A.: ibid., 56, 189-196 (1967)

16) McNelles, L.A. and Campbell, J.L.: ibid., 109, 241-251 (1973)

17）(財)日本分析センター：“容積試料の $\gamma$ 線スペク トロメトリーにお斿る自己吸収補正法”（1982）

18）本田哲太郎, 武田健治, 野口正安 : Radioisotopes, 27, 367-372 (1978)

19）武田健治, 本田哲太郎, 野口正安 : ibid., 28, 24-26 (1979) 
20) Noguchi, M., Takeda, K. and Higuchi, H.: Intern. J. Appl. Radiat. Isot., 32, 17-22 (1981)

21) Rieppo, R.: Nucl. Instr. \& Methods, 179, 155-158 (1981)

22) Nakamura, T. and Suzuki, T.: ibid., 205,
Nos. 1, 2, 211-218 (1983)

23) Curie, L.A.: Anal. Chem., 40, 586-593 (1968)

24) Altshuler, B. and Pasternack, B.: Health Phys., 9, 293-298 (1963)

25) Cooper, J.A.: Nucl. Instr. \& Methods, 82, 273-277 (1970) 